\title{
PROGRAM STEM UNTUK MELATIH KOLABORASI SISWA GUNA MEMPERSIAPKAN DIRI MENJADI ENGINEERING UNGGUL DI ABAD 21
}

\author{
Deny Nusyirwan ${ }^{1)}$, Eko Prayetno ${ }^{2)}$, Sapta Nugraha ${ }^{3)}$, Harits Aditya Nugraha4), Muhammad Andika ${ }^{5}$, \\ Muhammad Abyan Fadillah' \\ 1) Program Studi Teknik Perkapalan, Universitas Maritim Raja Ali Haji, e-mail : denynusyirwan@umrah.ac.id \\ 2) Program Studi Teknik Perkapalan, Universitas Maritim Raja Ali Haji, e-mail : ekoprayetno@umrah.ac.id \\ 3) Program Studi Teknik Elektro, Universitas Maritim Raja Ali Haji, e-mail : saptanugraha@umrah.ac.id \\ 4) Program Studi Teknik Elektro, Universitas Maritim Raja Ali Haji, e-mail : $180120201023 @$ student.umrah.ac.id \\ 5) Program Studi Teknik Elektro, Universitas Maritim Raja Ali Haji, e-mail : 170120201039 @ student.umrah.ac.id \\ 6) Program Studi Teknik Elektro, Universitas Maritim Raja Ali Haji, e-mail : $180120201022 @$ student.umrah.ac.id
}

\begin{abstract}
Abstrak
Pembelajaran terbaik terjadi ketika anak-anak secara aktif terlibat dalam suatu proyek. Pembelajaran kolaboratif merupakan pendekatan yang mendorong siswa untuk membuat kelompok dan bekerja sama untuk memecahkan suatu masalah yang diberikan. Sebagian besar dari pengajar percaya pada kekuatan kolaborasi dan sering melibatkan siswa dalam aktivitas kolaboratif.. Dengan latar tersebut di lakukan kegiatan pengabdian masyarakat dengan memberikan pelatihan keterampilan STEM untuk menumbuhkan kemampuan kolaborasi siswa Madrasah Ibtidaiyah Raudhatul Qur'an Tanjungpinang dalam mempersiapkan diri menghadapi era revolusi industri 4.0. Pelatihan ini dikenal juga dengan Tech for Kids. Kegiatan Tech for Kids di Madrasah Ibtidaiyah Swasta (MIS) Raudhatul Qur'an Kids dilaksanakan secara regular mingguan. siswa diberikan pemahaman mengenai permasalahan-permasalahan yang ditemukan di sekitar sekolah melalui metode etnografi. Pra-pengujian sangat membantu untuk mengukur pengetahuan siswa, atau pembelajaran kognitif, dan keterampilan. Dengan melakukan penilaian ini sebelum pelatihan akan membentuk fondasi untuk rencana pelatihan dan memastikan bahwa pelatihan yang sesuai dan relevan diberikan sehingga meningkatkan efektivitas latihan secara keseluruhan
\end{abstract}

Kata kunci:, ilmiah, proyek, siswa,STEM

\begin{abstract}
The best learning occurs when children are actively involved in a project. Collaborative learning is an approach that encourages students to create groups and work together to solve a given problem. Most of the teachers believe in the power of collaboration and often involve students in collaborative activities. With this background, community service activities are carried out by providing STEM skills training to foster collaboration skills of students at Madrasah Ibtidaiyah Raudhatul Qur'an Tanjungpinang in preparing for the era of industrial revolution 4.0. This training is also known as Tech for Kids. Tech for Kids activities at Raudhatul Qur'an Kids Private Madrasah Ibtidaiyah (MIS) are held regularly weekly. students are given an understanding of the problems found around the school through the ethnographic method. Pre-testing is helpful for measuring student knowledge, or cognitive learning, and skills. Carrying out this assessment before training will form the foundation for the training plan and ensure that appropriate and relevant training is provided thereby increasing the overall effectiveness of the exercise.
\end{abstract}

Keywords: project, scientific, students,STEM

\section{PENDAHULUAN}

Industri 4.0, yang disebut sebagai "Revolusi Industri Keempat", juga dikenal sebagai "manufaktur pintar", "internet industri", atau "industri terintegrasi", saat ini menjadi topik yang banyak dibahas yang berpotensi memengaruhi seluruh industri dengan mengubah cara barang dirancang, diproduksi, dikirim, dan dibayar (Hofmann dan Rüsch, 2017)

Dengan memberikan kesempatan kepada siswa untuk melakukan proyek-proyek ilmiah, maka kesadaran ilmiah siswa akan meningkat dan mereka mendapatkan wawasan tentang tantangan saat ini dan bagaimana insinyur menanggapinya (Depuydt, et al.,2018) 
Pembelajaran STEM membangun keterampilan yang dibutuhkan anak-anak untuk masa depan, dimana akan bekerja di pekerjaan yang kemungkinan belum ada saat ini, Kesenjangan teknologi saat ini dan masa depan akan semakin besar. Dengan memperkenalkan STEM pada sekolah dasar, bertujuan untuk mempersiapkan generasi berikutnya memiliki kemampuan untuk menciptakan masa depan yang lebih baik.

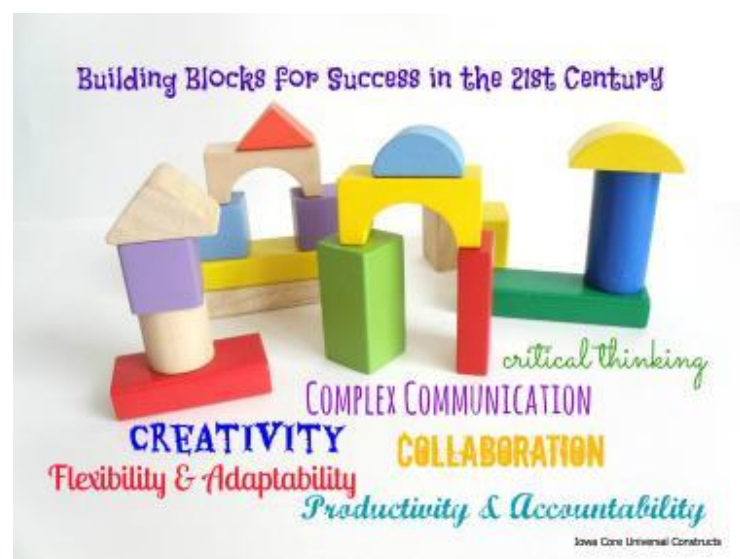

Gambar 1. Keterampilan Abad Ke-21 (https://lead-prep.org, 2020)

Banyak ekonom memprediksi bahwa disrupsi yang berkembang di berbagai industri ditumbulkan oleh percepatan evolusi teknologi pada abad ke-21. Kecerdasan buatan, robotika dan otomatisasi, bahan nano, dan adalah merupakan bentuk tsunami yang membawa perubahan pada proses bisnis dengan platform dan jaringan digital. Pada masa depan pekerjaan akan terus berubah. Untuk membantu siswa bertahan dan berkembang dalam lingkungan ketidakpastian tersebut maka perlu mempersiapkan siswa dengan apa yang disebut keterampilan abad ke21 (John Reaves, 2019).

Keterampilan abad ke-21 menitik beratkan pada kemampuan komunikasi (communication) sebagai dasar. Selanjutnya kemampuan bekerja sama (collaboration). Pemikiran kritis (critical thinking) diperlukan ketika menghadapi kompleksitas, ketidakpastian dan memecahkan masalah Selanjutnya kreativitas untuk menghasilkan desain yang berbeda atau inovatif (creator), berupa solusi yang unik atau tidak ada sebelumnya, sila lihat pada Gambar 1. Adap pembelajaran yang mendalam dihasilkan melalui integrasi yang disengaja dari konten akademis yang ketat dengan pengalaman yang secara sengaja menumbuhkan keterampilan, pola pikir, dan literasi yang penting bagi siswa untuk menjadi pembelajar dan kontributor seumur hidup di dunia kita yang berubah dengan cepat, sila lihat Gambar 2.

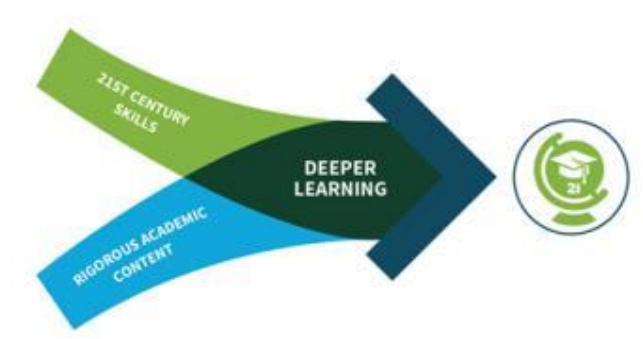

Gambar 2. Pembelajran Abad Ke-21

(https://www.battelleforkids.org, 2020)

Para pengajar perlu memberi anak-anak alat untuk melihat dunia mereka, menemukan masalah yang mereka minati, dan merancang solusi untuk mereka. Jenis pembelajaran Tech for Kids (TFK) dapat menjadi sarana untuk melatih keterampilan abad 21 kepada siswa seperti pemikiran sistem dan kolaborasi. Pada saat yang sama, pemecahan masalah di dunia nyata dapat mengungkap teknologi yang nantinya menjadi bagian integral dari pekerjaan dan kehidupan sehari-hari kita.

\section{PELAKSANAAN KEGIATAN}

Anak-anak mrmiliki kepribadian insinyur secara alami. Dimulai dengan rajin untuk mengotak-atik dan membangun serta membongkar dan menyatukannya kembali. Anak-anak mampu membuat penyesuaian secara cepat dan berimprovisasi tanpa memiliki rasa takut untuk menemukan sesuatu yang baru. Tidak semua kurikulum STEM dibuat sama, jadi penting bahwa saat mengintegrasikan STEM kepada siswa, dapat disusun sebuah program yang memungkinkan penelitian dan pemecahan masalah di dunia nyata. Salah satu cara untuk melakukannya adalah dengan mencari program STEM yang telah dirancang dengan menggunakan Engineering Design Process (EDP). Proses ini, memberi siswa kesempatan untuk mengembangkan proses pemecahan masalah yang merupakan solusi di dunia nyata. Dengan menguasai EDP, tidak mengatakan bahwa siswa akan tumbuh dan menjadi seorang insinyur, tetapi ada baiknya siswa mempelajari dan memahami apa yang 
dilakukan oleh seorang insinyur, yaitu proses memecahkan masalah melalui desain.

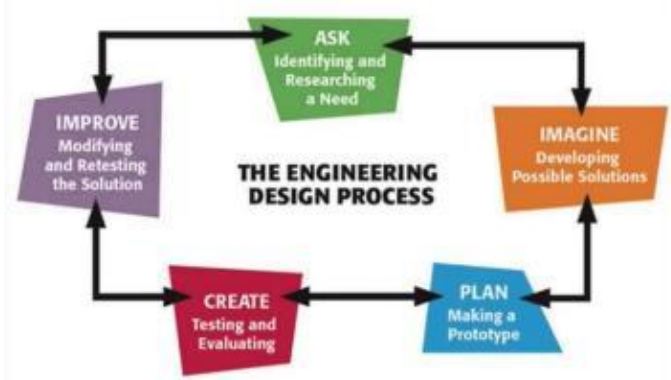

Gambar 3. Proses Desain Rekayasa (https://www.mrflemingscience.com, 2020)

Pada Gambar 3 menampilkan tahapan-tahapan dari EDP, dimulai dengan identifikasi masalah. Dimulai dengan identifikasi masalah, dilanjutkan dengan curahan gagasan/ide yang dikenal dengan istilah brainstorming. Dalam tahapan ini, siswa akan diajak untuk berpikir secara luas tanpa perlu membatasi diri untuk bisa atau tidak realisasi dari solusi yang diberikan. Luaran dari brainstorming akan di rancang dalam sketsa kertas dan di rakit dalam bentuk nya dengan mengguankan bahan-bahan sederhana. Hasil ahir dari solusi terhadap permasalahan di tunjukkan untuk memberikan informasi lengkap mengenai inovasi yang dihasilkan.

\section{HASIL DAN PEMBAHASAN}

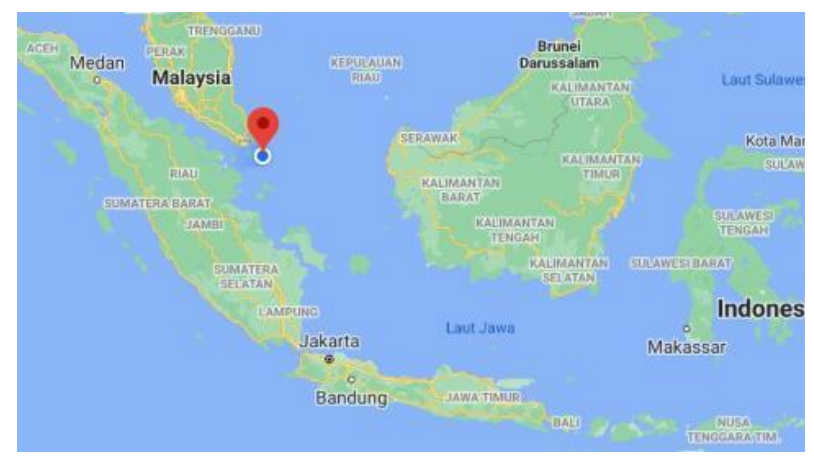

Gambar 4. Lokasi Madrasah Ibtidaiyah Raudhatul Qur'an (https://maps.app.goo.gl, 2020)

Kegiatan Tech for Kids di Madrasah Ibtidaiyah Swasta (MIS) Raudhatul Qur'an Kids dilaksanakan secara regular mingguan. Pada Gambar 4. menampilkan lokasi dari sekolah yang bertempat di bagian timur dari Kota Tanjung Pinang.
Tanjungpinang. Tanjungpinang adalah sebuah kota yang berlokasi di Pulau Bintan, Provinsi Kepulauan Riau. Lokasinya yang berdekatan dengan negara tetangga Malaysia dan Singapura, mendorong Kota Tanjungpinang untuk wajib memiliki SDM yang mampu menggerakkan ekonomi Provinsi Kepulauan Riau guna berkompetisi secara global.
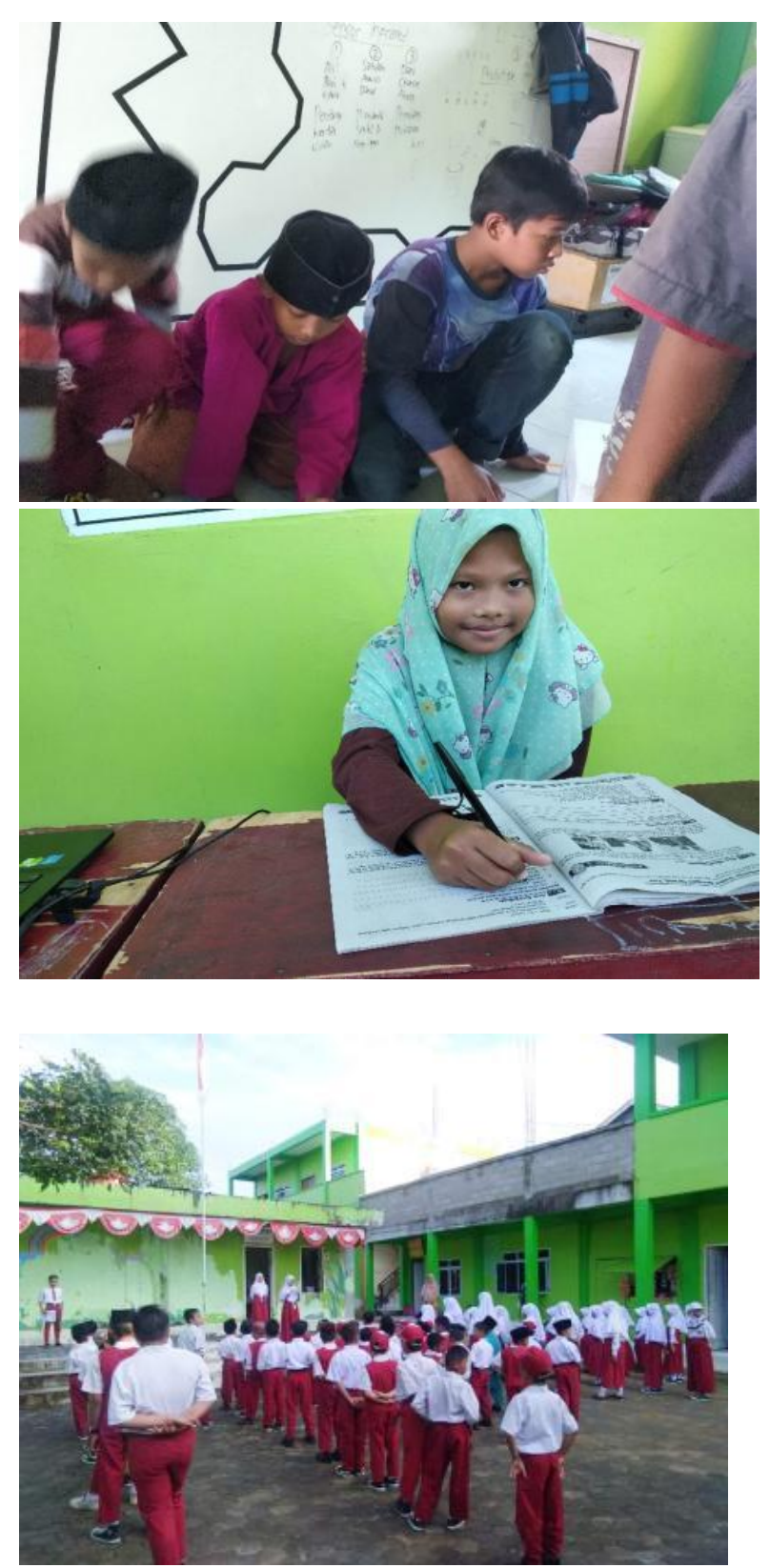

Gambar 5. Suasana madrasah ibtidaiyah raudhatul qur'an

Nama Raudhatul Qur'an diambil dari lokasi sekolah yang berada di tengah masyarakat. Sekolah dilengkapi dengan fasilitas ruang belajar, lapangan olahraga dan masjid. Pelajar yang menghadiri proses belajar mengajar di MI Raudhatul Qur'an pada pagi 
hari adalah siswa yang menempati Pondok Pesantren Raudhatul Qur'an dan siswa yang bertempat tinggal di luar pondok. Adapun pelatihan TFK di tujukan kepada siswa dan siswi yang bertempat tinggal didalam Pondok. Pada Gambar 5. menampilkan suasana Madrasah Ibtidaiyah (MI) Raudhatul Qur'an.

Pada pertemuan awal, dimulai dengan mengajak siswa untuk memahami pentingnya teknologi didalam kehidupan keseharian dan memperkenalkan TFK. Selanjutnya mengajak siswa untuk memahami secara singkat mengenai tahapan yang diperlukan untuk menghasilkan sebuah solusi dari masalah yang ditemukan, yang dikenal dengan Engineering Design Process (EDP) Pada Tabel 1. menampilkan agenda pelatihan TFK di Madrasah Ibtidaiyah Raudhatul Qur'an Tanjungpinang.

Tabel 1. Jadwal TFK di Madrasah Ibtidaiyah Raudhatul Qur'an Tanjungpinang

\begin{tabular}{|c|c|c|}
\hline & Bahan ajar & Pelaksana \\
\hline $\begin{array}{l}\text { Minggu } \\
\text { ke } 1-4 .\end{array}$ & $\begin{array}{l}\text { 1. Pengenalan } \\
\text { Tech for Kids } \\
\text { 2. Pengenalan } \\
\text { Engineering } \\
\text { Design } \\
\text { Process } \\
\text { 3. Observasi } \\
\text { lingkungan } \\
\text { dengan metode } \\
\text { etnografi } \\
\text { 4. Identifikasi } \\
\text { Permasalahan } \\
\text { melalui } \\
\text { Etnografi }\end{array}$ & $\begin{array}{l}\text { Dosen } \\
\text { Pendamping, } \\
\text { Mahasiswa } \\
\text { fasilisator dan } \\
\text { siswa/i }\end{array}$ \\
\hline $\begin{array}{l}\text { Minggu } \\
\text { ke 5-8 }\end{array}$ & $\begin{array}{l}\text { 1. Brainstorming } \\
\text { permasalahan } \\
\text { dan } \\
\text { menentukan } \\
\text { solusi. } \\
\text { 2. Mensketsa } \\
\text { 3. Virtual } \\
\text { Prototyping }\end{array}$ & $\begin{array}{l}\text { Dosen } \\
\text { Pendamping, } \\
\text { Mahasiswa } \\
\text { fasilisator dan } \\
\text { siswa/i }\end{array}$ \\
\hline $\begin{array}{l}\text { Minggu } \\
\text { ke } 9-12\end{array}$ & $\begin{array}{l}\text { 1. Purwarupa } \\
\text { sederhana }\end{array}$ & $\begin{array}{l}\text { Dosen } \\
\text { Pendamping, } \\
\text { Mahasiswa } \\
\text { fasilisator dan } \\
\text { siswa/i }\end{array}$ \\
\hline
\end{tabular}

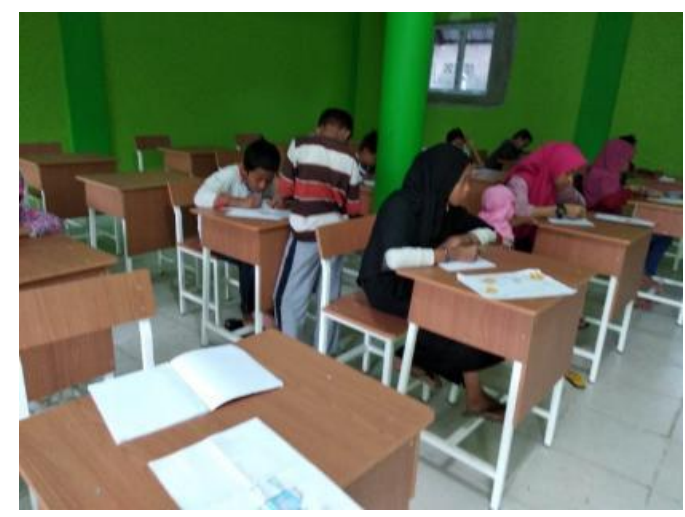

Gambar 6. Suasana pembelajaran pada pertemuan pertama

Adapun nama mahasiswa yang menjadi fasilisator dalam pelatihan dan siswa yang terlibat dalam pelatihan Tech for Kids dapat dilihat pada Tabel 2.

Dalam tahapan identifikasi permasalahan melalui etnografi dan brainstorming, siswa diberikan pemahaman mengenai permasalahan-permasalahan yang ditemukan di sekitar sekolah melalui metode etnografi. Etnografi sudah dikenal luas tidak hanya oleh kalangan antropologi namun juga oleh perusahaan yang bergerak di bidang inovasi. Dengan memanfaatkan metode etnografi, maka informasi yang dikumpulkan akan lebih akurat. Etnografi berasal dari kata etno dan grafi, yang berarti etnik dan daerah. Proses Etnografi adalah proses mempelajari pola hidup masyarakat di suatu daerah melalui pendekatan secara sosial. Pada Gambar 7 menunjukkan mahasiswa sebagai fasilisator pelatihan Tech for Kids mendampingi siswa untuk mengenal etnografi .

Didalam proses brainstorming, setiap pendapat dapat diterima. Proses yang dikenal juga dengan sebutan proses divergent. Curahan gasan merupakan bagian penting seorang rekayasawan untuk mempu menghasilkan inovasi yang bermanfaat secara luas di sekolah nantinya seperti pada Gambar 8. 
Table 2. Data peserta dan fasilisator pendamping tech for kids tahun 2020

\begin{tabular}{llll}
\hline $\begin{array}{l}\text { Nama } \\
\text { Sekolah }\end{array}$ & Dosen Pembimbing & Siswa & $\begin{array}{c}\text { Fasilisator } \\
\text { pendamping }\end{array}$ \\
\hline Madrasah & 1.Deny Nusyirwan, S.T., & 1. Aril Ramadhan & 1.Harits Aditya \\
Ibtidaiyah & M.Sc. & 2. Sahdana Fauzi Latif \\
Raudhatul & 2.Eko Prayetno, S.T., & 3. Dani Meldani Warta & 2.M. Andika \\
Qur'an & M.Eng & 4. Kevin Wijaya Kusuma & 3.M. Abyan \\
& 3.Sapta Nugraha, S.T., & 5. Muhammad Ridwan & Fadillah \\
& M.Eng & 6. Ahsanul Khaliq Yunus & \\
& 7. Anton Hekso Yunianto, Ahsin Yunus & \\
& 8.T., M.Si & 9. Muhammad Hafizul Ahkam & \\
& 5.Tonny Suhendra, S.T., & 10. Charly Muhammad Nazrul & \\
& M.Cs. & 11. Sahdina Fauzia Herlan & \\
& 12. Putri Yarni Tari & 13. Kesya Septia Aliska \\
& 14. Aulia Alawia Zen & 15. Kanaya Amelia Putri \\
& 16. Liren Aprilia Larensa & 17. Sanisa Mutiara Koto \\
\end{tabular}

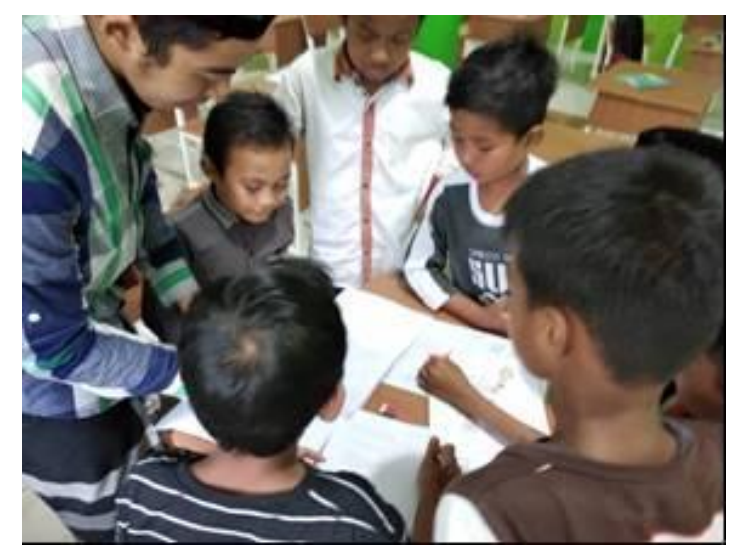

Gambar 7. Mahasiswa berintegrasi langsung dengan siswa

Insinyur harus menganalisis dan memecahkan berbagai masalah teknis. Beberapa akan menjadi masalah dengan desolusi tunggal yang cukup sederhana atau terbuka dan kemungkinan akan membutuhkan tim insinyur dari beberapa disiplin ilmu. Bahkan beberapa masalah mungkin tidak memiliki solusi yang jelas. Masalah bukan sekadar situasi yang tidak diinginkan. masalah adalah kebutuhan yang tidak terpenuhi yang, jika dipenuhi, dapat memenuhi tujuan pengguna. Desain yang dipilih harus mewakili solusi yang menurut siswa paling sesuai dengan kebutuhan atau memecahkan masalah yang diidentifikasi pada awal proses.

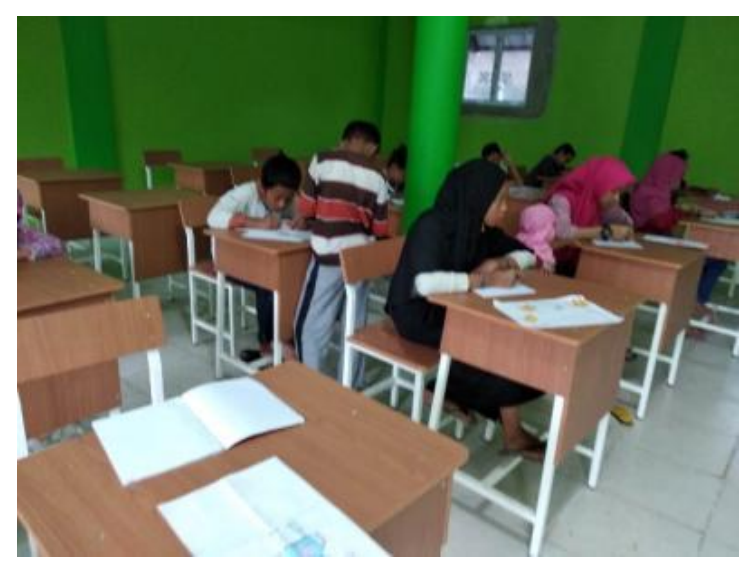

Gambar 8. Siswa dan siswi melakukan curahan gagasan

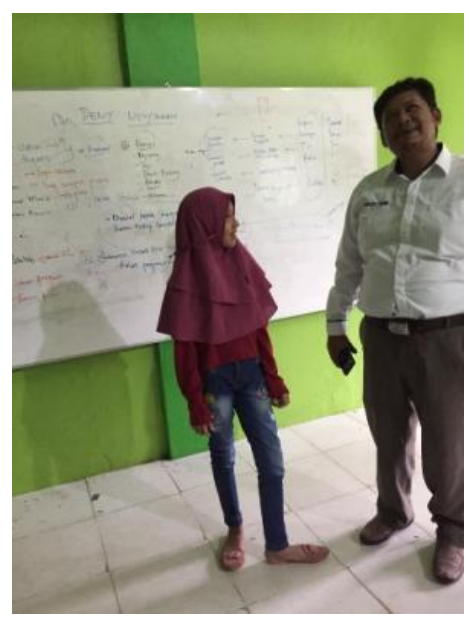

Gambar 9. Proses curahan gagasan 


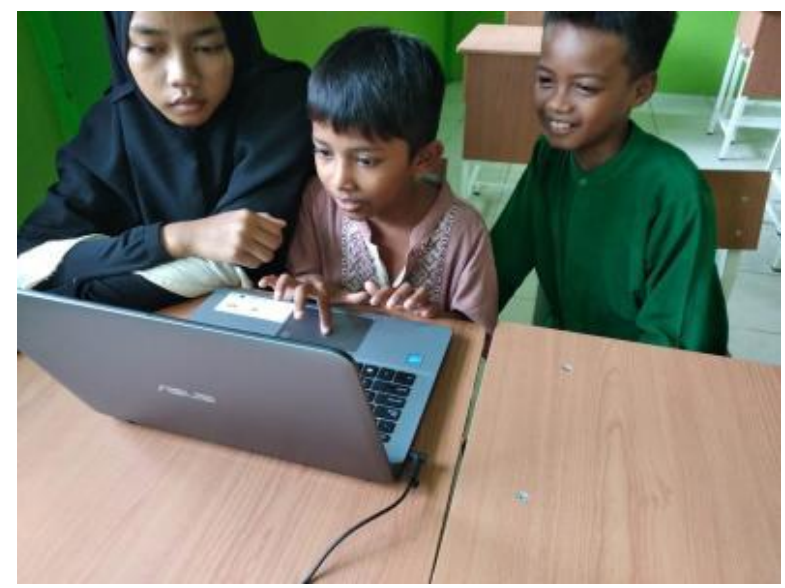

Gambar 10. Pembuatan purwarupa virtual

Pada Gambar 9. menampilkan proses curahan gagasan untuk mendorong siswa menyampaikan permasalahan utama dan meberikan solusi utama secara bebas

Pembuatan purwarupa virtual sangat berguna jika produksi purwarupa fisik mahal dan memakan waktu serta diperlukan pendekatan berulang untuk pengembangan dan evaluasi, khususnya jika tidak ada pedoman atau standar desain yang ditetapkan sebelumnya. Oleh sebab itu, dengan menggunakan purwarupa memungkinkan desainer mengeksplorasi dan memvalidasi ide sebelum menginvestasikan terlalu banyak sumber daya dalam membangun produk yang sebenarnya (Elverum, et al.,2018)

Purwarupa virtual adalah bentuk digital dari purwarupa fisik. Dengan dimulainya kemajuan teknologi, ppurwarupa awal juga mengalami beberapa perubahan. Purwarupa virtual adalah salah satu dari banyak hasil digitalisasi dalam revolusi industri keempat. Awalnya purwarupa fisik dibuat dari desain yang dibuat pada perangkat lunak Computer Aided Design (CAD) 3 Dimensi untuk tujuan pengujian. Dengan penggerak otomasi yang mendominasi era Industri 4.0, kebutuhan untuk pembuatan purwarupa fisik, yang merupakan proses yang memakan waktu dan mahal, dihilangkan dengan pengenalan Purwarupa Virtual.

Adapun Purwarupa fisik dan visual memiliki tujuan yang sama namun dengan cara pencapaian yang berbeda (Gibson, et al.,2018)

Tahapan pembuatan purwarupa fisik sederhana adalah merupakan tahapan dari Proses Desain Rekayasa yang sudah mulai memerlukan pembiayaan. Oleh sebab itu pada tahapan ini, perancang akan memulai pembuatan purwarupa yang ekonomis dan fleksible, dengan maksud bahwa perubahan rancangan dapat dilakukan dengan mudah dan tidak akan memerlukan pembiayaan yang besar. Penentuan jenis purwarupa yang akan dipergunakan ditentukan dengan mempertimbangkan waktu, biaya dan pengalaman dari setiap siswa. Pada Gambar 11 menampilkan aktifitas siswa didalam merakit purwarupa fisik dari bahan-bahan ekonomis dan sederhana.
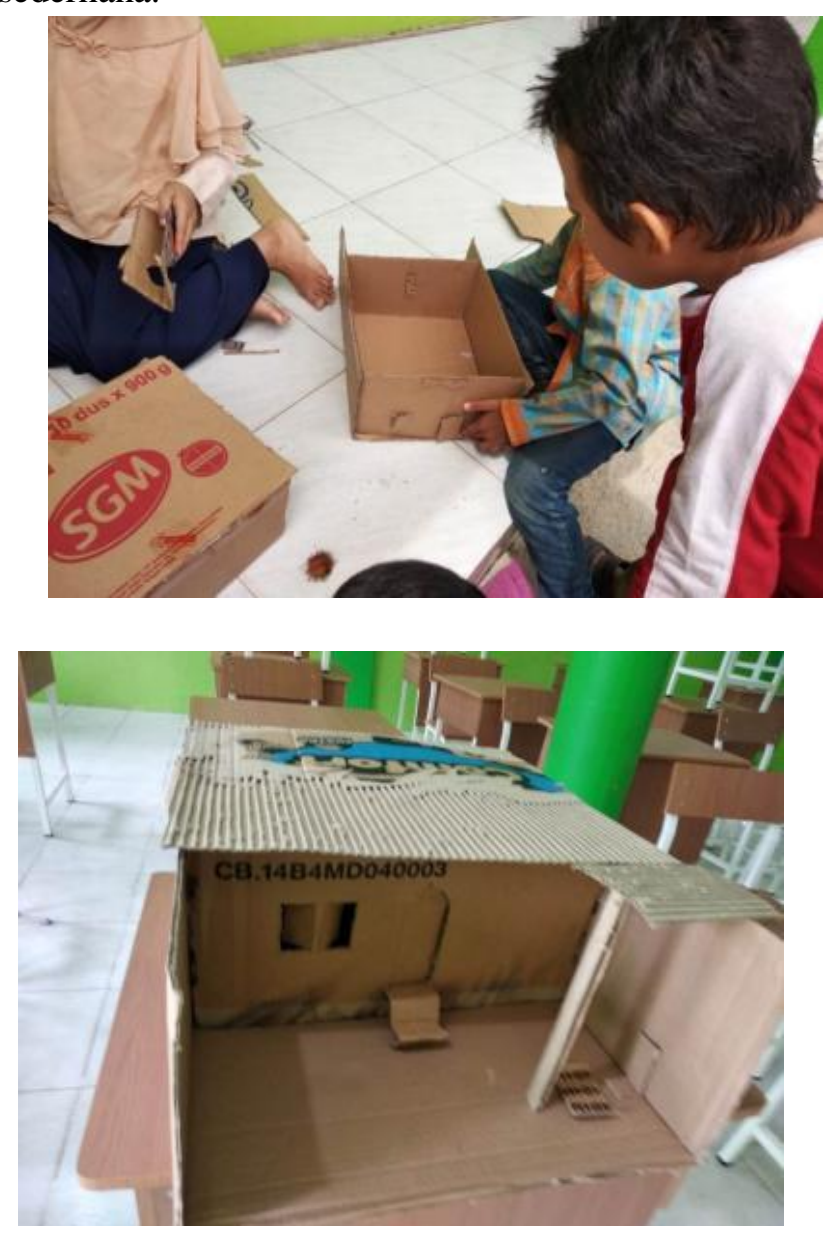

Gambar 11. Perakitan Purwarupa Fisik Sederhana Dan Ekonomis

Pembelajaran terbaik terjadi ketika anak-anak secara aktif terlibat dalam suatu proyek. Pembelajaran kolaboratif merupakan pendekatan yang mendorong siswa untuk membuat kelompok dan bekerja sama untuk memecahkan suatu masalah yang diberikan. Sebagian besar dari pengajar percaya pada kekuatan kolaborasi dan sering melibatkan siswa dalam aktivitas kolaboratif. Tetapi berapa kali pengajar menempatkan siswa dalam kelompok hanya untuk melihat mereka berinteraksi dengan laptop mereka, bukan dengan satu sama lain atau mengeluh tentang rekan setim yang malas. Mempromosikan kolaborasi 
nyata sulit dilakukan dengan baik dan tidak terjadi begitu saja. Jika menginginkan kolaborasi siswa yang nyata, maka perlu dengan sengaja mendesainnya sebagai bagian dari kegiatan belajar.

Pada Tabel 3. menampilkan parameter pengukuran Pelatihan Tech for Kids di MIS Raudhatul Qur'an Tanjungpinang Timur terkait keterampilan sosial dan lintas budaya, yaitu kemampuan untuk menampilkan hasil pekerjaan.

Menilai siswa ketika mereka pertama kali memasuki suatu program dapat menetapkan tolok ukur yang kuat untuk mengukur pertumbuhan atau nilai tambah, sila lihat Gambar 12. Pra-pengujian sangat membantu untuk mengukur pengetahuan siswa, atau pembelajaran kognitif, dan keterampilan. Dengan melakukan penilaian ini sebelum pelatihan akan membentuk fondasi untuk rencana pelatihan dan memastikan bahwa pelatihan yang sesuai dan relevan diberikan sehingga meningkatkan efektivitas latihan secara keseluruhan. Pelatihan adalah proses memperoleh keterampilan, kompetensi dan pengetahuan untuk melakukan peran apa pun secara efektif dan karena itu biasanya memiliki fokus praktis. Sangat jarang untuk menemukan seseorang yang dapat memasuki suatu pekerjaan dengan semua keterampilan, pengetahuan dan atribut yang dibutuhkan untuk berhasil melakukan pekerjaan ke tingkat yang optimal sejak hari pertama, seperti pada Gambar 13.

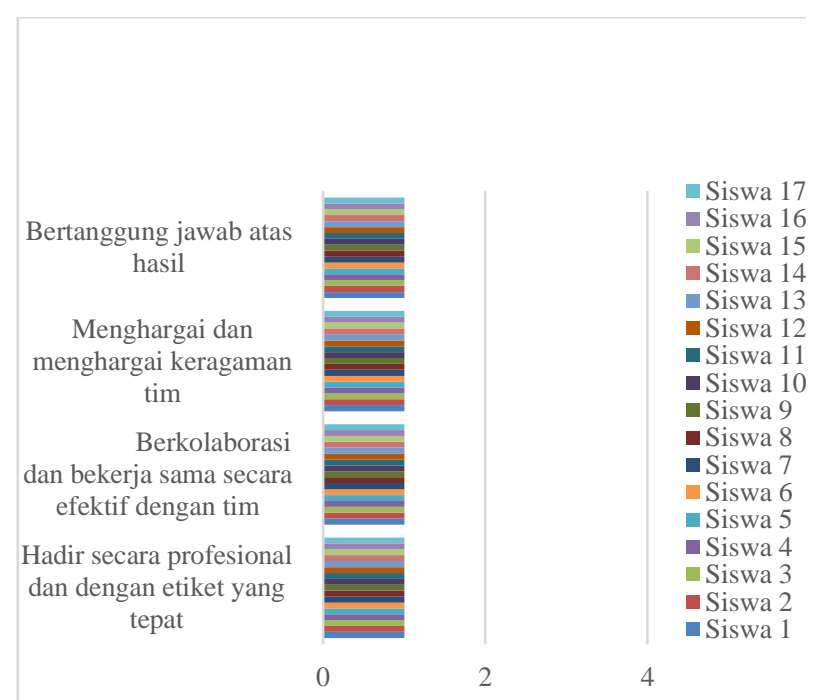

Gambar 12. Kondisi Pada Penilaian Awal Siswa.

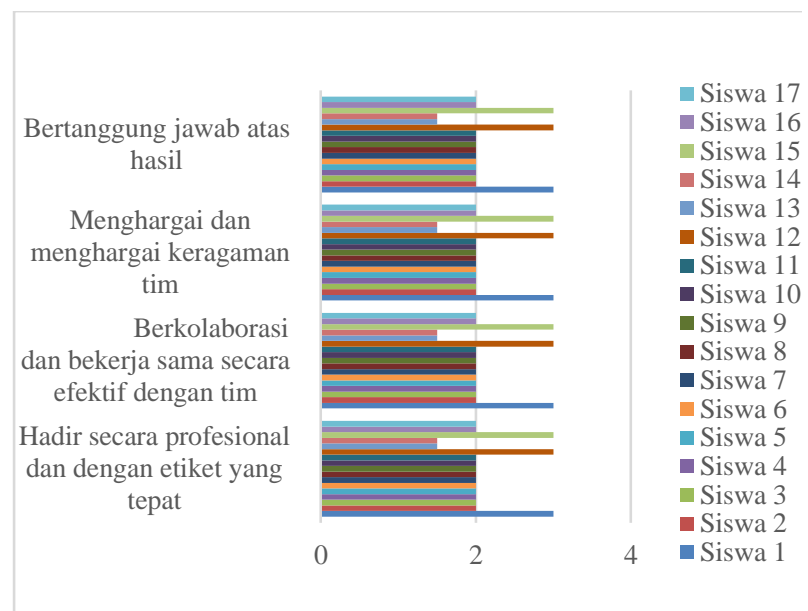

Gambar 13. Hasil Pelatihan Tech for Kids di MIS Raudhatul Qur'an Tanjungpinang Timur 
Tabel 3. Parameter Yang Dipergunakan Untuk Mengukur Hasil Pelatihan Keterampilan Sosial dan Lintas Budaya

\begin{tabular}{|c|c|c|c|c|}
\hline \multicolumn{5}{|c|}{ Hasil } \\
\hline & $\begin{array}{c}4 \\
\text { Sangat Baik }\end{array}$ & $\begin{array}{c}3 \\
\text { Baik } \\
\end{array}$ & $\begin{array}{c}2 \\
\text { Cukup } \\
\end{array}$ & $\begin{array}{c}1 \\
\text { Kurang } \\
\end{array}$ \\
\hline $\begin{array}{c}\text { Hadir secara } \\
\text { profesional } \\
\text { dan dengan } \\
\text { etiket yang } \\
\text { tepat }\end{array}$ & $\begin{array}{c}\text { Perilaku dan } \\
\text { pakaian selalu } \\
\text { sesuai untuk acara } \\
\text { ini. Selalu bertindak } \\
\text { dengan hormat } \\
\text { terhadap orang lain. }\end{array}$ & $\begin{array}{l}\text { Menampilkan } \\
\text { perilaku dan gaun } \\
\text { profesional dan } \\
\text { bertanggung jawab } \\
\text { dengan tepat untuk } \\
\text { acara ini . } \\
\text { Berperilaku dengan } \\
\text { hormat terhadap } \\
\text { orang lain. }\end{array}$ & $\begin{array}{c}\text { Tidak selalu } \\
\text { menampilkan } \\
\text { perilaku } \\
\text { profesional dan } \\
\text { bertanggung } \\
\text { jawab. Kadang- } \\
\text { kadang } \\
\text { berpakaian } \\
\text { dengan tepat } \\
\text { untuk acara ini. } \\
\text { Kadang-kadang } \\
\text { bertindak } \\
\text { dengan hormat } \\
\text { terhadap orang } \\
\text { lain. }\end{array}$ & $\begin{array}{c}\text { Tidak } \\
\text { menampilkan } \\
\text { perilaku } \\
\text { profesional atau } \\
\text { bertanggung jawab. } \\
\text { Gaun yang jarang } \\
\text { sekali untuk acara } \\
\text { ini. Seringkali tidak } \\
\text { bertindak dengan } \\
\text { hormat terhadap } \\
\text { orang lain. }\end{array}$ \\
\hline $\begin{array}{l}\text { Berkolaborasi } \\
\text { dan bekerja } \\
\text { sama secara } \\
\text { efektif } \\
\text { dengan tim }\end{array}$ & $\begin{array}{l}\text { Secara konsisten } \\
\text { mendengarkan } \\
\text { orang lain dan ide- } \\
\text { ide mereka; } \\
\text { membantu mereka } \\
\text { mengembangkan } \\
\text { ide-ide mereka } \\
\text { sambil memberi } \\
\text { mereka kredit } \\
\text { penuh; membantu } \\
\text { tim mencapai } \\
\text { potensi penuhnya }\end{array}$ & $\begin{array}{l}\text { Mendengarkan sudut } \\
\text { pandang orang lain; } \\
\text { selalu menggunakan } \\
\text { bahasa yang tepat } \\
\text { dan terhormat; } \\
\text { mencoba untuk } \\
\text { membuat upaya yang } \\
\text { pasti untuk } \\
\text { memahami gagasan } \\
\text { orang lain. }\end{array}$ & $\begin{array}{l}\text { Kadang-kadang } \\
\text { mendengarkan } \\
\text { orang lain, dan } \\
\text { sering } \\
\text { menganggap } \\
\text { gagasan orang } \\
\text { lain tidak akan } \\
\text { berfungsi; } \\
\text { mencoba } \\
\text { bekerja dengan } \\
\text { baik bersama } \\
\text { tim. }\end{array}$ & $\begin{array}{c}\text { Berdebat dengan } \\
\text { orang lain '; tidak } \\
\text { mendengarkan } \\
\text { pendapat dan ide } \\
\text { kelompok ; ingin } \\
\text { hal-hal dilakukan } \\
\text { dengan cara mereka } \\
\text { dan tidak } \\
\text { mendengarkan } \\
\text { pendekatan } \\
\text { alternatif. }\end{array}$ \\
\hline $\begin{array}{l}\text { Menghargai } \\
\text { dan } \\
\text { menghargai } \\
\text { keragaman } \\
\text { tim }\end{array}$ & $\begin{array}{c}\text { Secara konsisten } \\
\text { mendengarkan } \\
\text { orang lain. Semua } \\
\text { pernyataan, } \\
\text { tanggapan, dan } \\
\text { bahasa tubuh, } \\
\text { adalah sopan dan } \\
\text { sesuai. Selalu } \\
\text { mendengarkan, } \\
\text { berbagi dengan, dan } \\
\text { mendukung upaya } \\
\text { orang lain. }\end{array}$ & $\begin{array}{l}\text { Mendengarkan, } \\
\text { berbagi, dan } \\
\text { mendukung orang } \\
\text { lain. S tatements dan } \\
\text { tanggapan yang } \\
\text { bahasa tubuh hormat } \\
\text { dan sesuai } \\
\text { dipamerkan. }\end{array}$ & $\begin{array}{c}\text { Sebagian besar } \\
\text { pernyataan, } \\
\text { tanggapan, dan } \\
\text { bahasa tubuh } \\
\text { sangat dihargai; } \\
\text { kadang - kadang } \\
\text { memiliki nada } \\
\text { negatif. Tidak } \\
\text { selalu } \\
\text { mendengarkan, } \\
\text { berbagi dengan, } \\
\text { dan mendukung } \\
\text { upaya orang } \\
\text { lain. }\end{array}$ & $\begin{array}{c}\text { Pernyataan, } \\
\text { tanggapan dan / } \\
\text { atau bahasa tubuh } \\
\text { secara konsisten } \\
\text { tidak menghormati. } \\
\text { Jarang } \\
\text { mendengarkan, } \\
\text { berbagi dengan, } \\
\text { dan mendukung } \\
\text { upaya orang lain }\end{array}$ \\
\hline $\begin{array}{c}\text { Bertanggung } \\
\text { jawab atas } \\
\text { hasil }\end{array}$ & $\begin{array}{l}\text { Secara konsisten } \\
\text { dan akurat } \\
\text { menyelesaikan } \\
\text { tugas dan } \\
\text { mengambil } \\
\text { tanggung jawab } \\
\text { untuk bekerja. }\end{array}$ & $\begin{array}{l}\text { Tanggung jawab } \\
\text { akes untuk pekerjaan } \\
\text { selesai. }\end{array}$ & $\begin{array}{c}\text { Terkadang } \\
\text { mengambil } \\
\text { tanggung jawab } \\
\text { terbatas untuk } \\
\text { tidak } \\
\text { menyelesaikan } \\
\text { pekerjaan. }\end{array}$ & $\begin{array}{l}\text { Tidak mengambil } \\
\text { tanggung jawab } \\
\text { untuk diselesaikan } \\
\text { pada pekerjaan } \\
\text { yang tidak selesai. }\end{array}$ \\
\hline
\end{tabular}




\section{PENUTUP}

\section{Kesimpulan}

Kegiatan Tech for Kids di Madrasah Ibtidaiyah Swasta (MIS) Raudhatul Qur'an Kids dilaksanakan secara regular mingguan. siswa diberikan pemahaman mengenai permasalahanpermasalahan yang ditemukan di sekitar sekolah melalui metode etnografi. Pra-pengujian sangat membantu untuk mengukur pengetahuan siswa, atau pembelajaran kognitif, dan keterampilan. Dengan melakukan penilaian ini sebelum pelatihan akan membentuk fondasi untuk rencana pelatihan dan memastikan bahwa pelatihan yang sesuai dan relevan diberikan sehingga meningkatkan efektivitas latihan secara keseluruhan

\section{Saran}

Pelatihan yang dilaksanakan telah menunjukkan bahwa anak-anak yang masih duduk di bangku sekolah dasar mampu mengikuti pelatihan berbasiskan pola pikir insinyur dengan baik. Pengenalan Teknologi yang dilakukan dengan pendekatan fun telah berhasil yang didampingi oleh mahasiswa sebagai fasilisator telah berdampak positif. Diharapkan kedepannya, kegiatan masih dapat berlangsung secara rutin dan mendapatkan dukungan dari pemerintah daerah setempat dan pihak swasta.

\section{DAFTAR PUSTAKA}

Critical Thinking in the 21st Century [Daring], Tersedia pada : https://leadprep.org/2013/07/critical-thinking-in-the-21stcentury/ [Diakses : 16 September 2020 ].

Depuydt, D., Hendrickx, K., Mehdikhani, M., Petrov, N. A., Lomov, S. V., dan Seveno, D. (2018). First steps in composite materials for schoolchildren: A STEM educational project, Composites Part A: Applied Science and Manufacturing, Vol. 109 : 298-302

Elverum, C. W., Welo, T., dan Tronvoll, S. (2016). Prototyping in New Product Development: Strategy Considerations.
Engineering Design Process [Daring], Tersedia pada

https://www.mrflemingscience.com/engineeringdesign-process.html [Diakses : 16 September 2020 ].

Gibson, I., Gao, Z., dan Campbell, R. I. (2004). A comparative study of virtual prototyping and physical prototyping, International Journal of Manufacturing Technology and Management Vol. , No. 6, hal 503-522

Hofmann, E., dan Rüsch, M. (2017). Industry 4.0 and the current status as well as future prospects on logistics, Computers in Industry, Vol. 89 : 23-34

Madrasah Ibtidaiyah Raudhatul Qur'an, Gg. Kano, Air Raja, Kec. Tanjungpinang Tim., Kota Tanjung Pinang, Kepulauan Riau 29125 [Daring], Tersedia pada : https://maps.app.goo.gl/1FyEQSRZQ6pjScjT9

[Diakses : 16 September 2020].

Reaves, J. (2019). 21st-Century Skills And The Fourth Industrial Revolution: A Critical Future Role For Online Education, International Journal on Innovations in Online Education, Vol 3, No 1

The Journey to 21st Century Learning for All Students [Daring], Tersedia pada : https://www.battelleforkids.org/learninghub/learning-hub-item/the-journey-to-21stcentury-learning-for-all-students [Diakses : 16 September 2020 ]. 